\title{
Comparative Palatability of Atriplex
}

\section{canescens}

\section{NASSER NEMATI}

Highlight: An Atriplex canescens introduced to Iran and two native species, Artemisia herba alba and Kochia prostrata, were fed to sheep throughout a year to determine the comparative palatability of the Atriplex. The Kochia has the highest and Artemisia has the lowest palatability when provided at two amounts on adjacent days. Atriplex is of intermediate palatability in comparison with the two native species.

Millions of hectares of arid and semiarid western states of the United States are covered by saltbush (Atriplex spp.) plants upon which millions of meat animals graze each year. Many saltbushes are reasonably good forage plants wherever they grow (Bidwell and Wooton 1925). The ability of saltbushes to put out new growth in dry years when annual plants fail, makes these plants valuable for intensive year-round grazing practices (Sankary and Barbour 1972). The value of the saltbushes will be better appreciated when it is remembered that in the selection of foods, the chief nutrients to be considered are protein compounds or nitrogenous ingrediets.

Saltbushes are eaten readily by sheep, goats, cattle, and horses when other feed is scarce. Desert saltbush (Atriplex polycarpa) has high forage value during the cool season of the year (Chatterton et al. 1971). Leafy twigs of saltbushes have a nutritive value comparable with alfalfa (Cassady 1937). Superior palatability, productivity, and adaptability are three qualities that make fourwing saltbush (Atriplex canescens) a favorable plant for game animals (Plummer et al. 1966).

Fourwing saltbush is adapted to harsh environment and has been used extensively in Iran for planting in the Steppic Arid and SemiArid Zone. Thousands of hectares receiving precipitation of about 100-230 mm annually have been improved through transplanting. However, in Iran there is little information about the palatability of fourwing saltbush to local sheep.

The objective of this study was to determine palatability of fourwing saltbush as compared with two important native species.

\section{Methods and Procedures}

A study was conducted at Homand Range Research Station $(80 \mathrm{~km}$ east of Tehran) in cooperation with the Research Institute for Forest and Rangeland. In this study, six sheep were given free access to utilize fresh cuttings of Artemisia herba alba, Atriplex canescens, and Kochia prostrata placed in food pans in each of three feed lots. Each feed lot was divided into three sublots. The cuttings of the three species were put into the sublots separately by random. Two levels of feed were provided on different days. At one level, $1.8 \mathrm{~kg}$ of the cuttings were put in each sublot and in the other level $2.0 \mathrm{~kg}$ of the cuttings were put in sublots for a 24-hour period. The amount of plant material remaining in each sublot after each 24-hour period was

\footnotetext{
The author is deputy director general of Range Management Department, Ministry of Agriculture and Natural Resources, Tehran, Iran

Manuscript received October 18, 1976
}

weighed and recorded separately. This study was continued for about 1 year.

For the statistical analysis, the analysis of variance was made on the mean grams used data, calculated from data for each species, amount, and lot summed over the days the study was conducted. The design was a randomized block with amount on adjacent days as a split plot. Significance was based on $95 \%$ probability.

\section{Results and Discussion}

Differences in utilization of species, amount, and the interaction between species and amount were found to be significant. Kochia

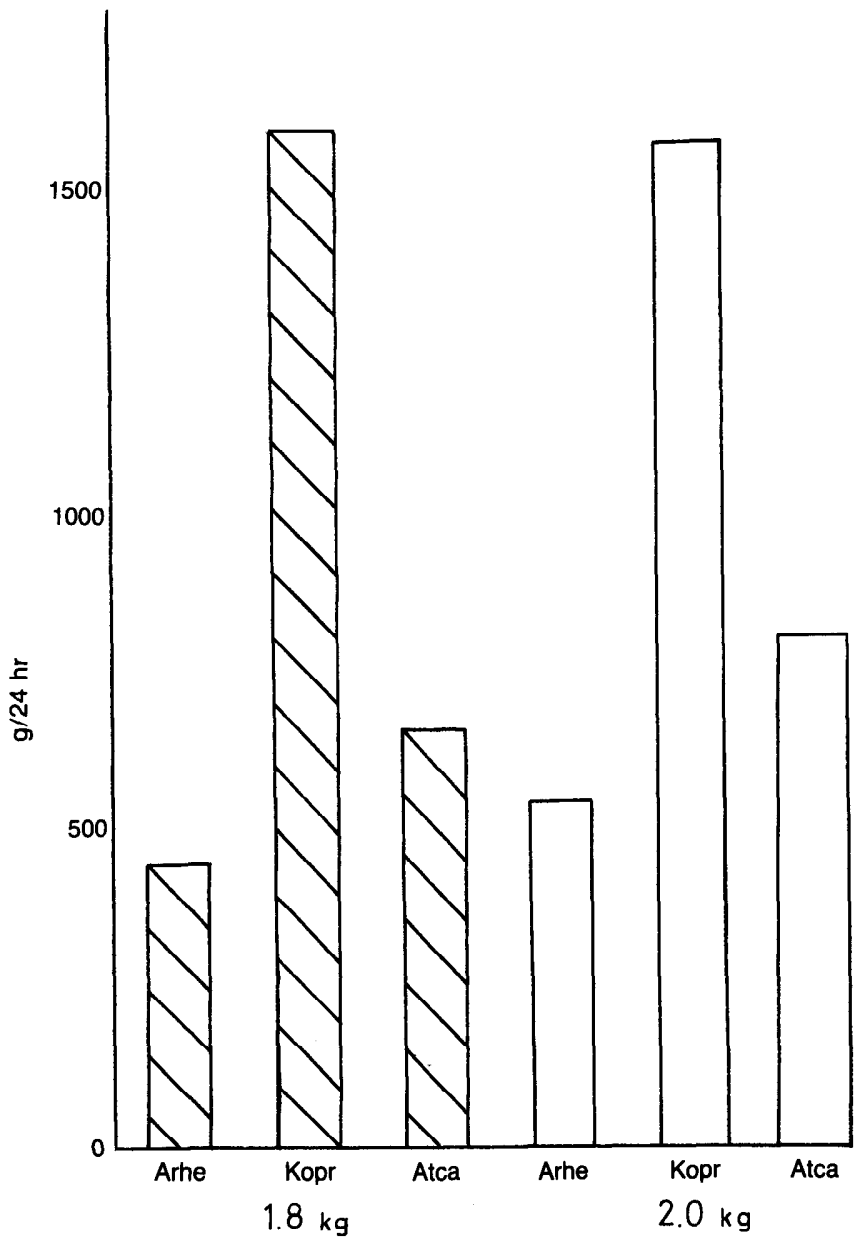

Fig. 1. Mean grams of forage of Artemisia herba alba (Arhe), Atriplex canescens (Atca), and Kochia prostrata (Kopr) used per 24 hours by six sheep when provided at two amounts on adjacent days. 
prostrata had the highest utilization at both 1.8 and $2.0 \mathrm{~kg}$ level (Fig. 1). Artemisia herba alba at both levels received the lowest utilization. The mean utilization at the $2.0 \mathrm{~kg}$ level was higher than at the $1.8 \mathrm{~kg}$ level. The mean utilization of Kochia prostrata was the highest, and Artemisia herba alba was the lowest (Fig. 1). In Iran it has long been accepted that Kochia prostrata had a higher forage value than Artemisia herba alba. Thus, Atriplex canescens had a palatability intermediate between the two species to which it was compared.

\section{Conclusion}

Statistical analysis shows that the differences in utilization of species, amount, and interaction between species and amount are significant. Artemisia herba alba is the least and Kochia prostrata is the most palatable of these two native species. The palatability of Atriplex canescens is intermediate when compared with two other native species. Because of the success that has been achieved in establishing Atriplex canescens in large scale plantings, Atriplex canescens as a forage plant has considerable promise in Iran.

\section{Literature Cited}

Bidwell, G. L., and Wooton, E. O. 1925. Saltbushes and their allies in the United States. U.S. Dep. Agr. Bur. of Chem. and Bur. of Plant Industry Bull. 1345.

Cassady, J. T. 1937. Chamiza browse on southwestern range and ways to increase it. U.S. Dep. Agr., Forest Serv., Southwestern Forest and Range Exp. Sta. Res. Note No. 23. 5 p.

Chatterton, N. J., J. R. Goodin, C. M. McKell, R. V. Parker, and J. M. Rible. 1971. Monthly variation in chemical composition of desert saltbush. J. Range Manage. 24:37-40.

Plummer, A. P., S. B. Monsen, and D. R. Christensen. 1966. Fourwing saltbush-a shrub for future game range. Utah State Dep. Fish and Game Pub. No. 66-4.

Sankary, M. N., and M. G. Barbour. 1972. Autecology of Artiplex polycarpa from California. Ecology 53:995-1229.

\section{AWARD NOMINATIONS}

The SRM Honor Awards program includes the Frederic G. Renner Award, Fellow of the Society for Range Management Award, and the Outstanding Achievement Award.

Nominations may be made by any member, officer, or committee having actual knowledge of the nominee's achievements. Nomination should be made by letter to the chairman of the Honor Awards Committee. The letter should state the nominee's name and address, the award for which the person is being nominated, and a brief statement of the nominee's qualifications.

Nominations made before February 1, 1978, will be considered for awards to be presented at the Society annual meeting in February, 1979.

When making a nomination it is important to select the award for which the nominee is qualified. Use the following criteria as a guide:

\section{Frederic G. Renner Award}

The Frederic G. Renner Award gives special recognition to individuals for their exceptional accomplishments in, or contributions to, range management. It is the highest award bestowed on an individual by the Society.

The primary criterion for this award is current outstanding accomplishment(s) in or contribution(s) to any aspect of range science and range management (viz. current is considered to be within the past 5 years). Accomplishments or contributions may be in, but not necessarily limited to, such areas as range management practice, research, administration, teaching, writing, legislation, foreign affairs, business activities or public relations. Any individual, or small group of individuals working as a close team (e.g. research team or ranch owner and foreman), is eligible for nomination for this award. Institutions, agencies, or other formally organized groups are not eligible. Neither membership in SRM nor U.S. citizenship is necessary.

\section{Fellow Award}

The title of Fellow is conferred upon members of the SRM in recognition of exceptional service to the Society and its programs. This honor is granted in the belief that special recognition should be given for dedicated service and professional involvement.

Primary criterion is tangible evidence that the exceptional service performed by the nominee is widely effective and generally recognized throughout the Society. Evidence must support a strong case history of continuous contribution and service. Membership in the Society for at least ten consecutive years and evidence of significant participation in, and contribution to, progress of the Society during this period is required. This award will not be granted to recognize long and faithful service in lieu of the above criteria.

\section{Outstanding Achievement Award}

Presented to individuals whose contributions or careers have become eminently noteworthy in the advancement of the science and art of range related resource management. This award is presented as an encouragement for outstanding achievement by members and other qualified individuals working with rangeland resources.

The primary requisite for this award is tangible evidence that the contributions or the career of the nominee is eminently noteworthy. Emphasis should be given to acknowledging currently recognized eminence. This award will not be given to recognize long and faithful service or occupation of a distinguished position in lieu of tangible evidence of noteworthy achievement as indicated above. Neither membership in SRM nor U.S. citizenship is required.

The Committee Chairman will request that each nominee submit a written documentary of his past and current achievements and contributions and other qualifications. An outline will be provided for this purpose.

James E. Bowns, Chairman, Honor Awards Committee, Southern Utah State College, Cedar City, Utah 84720. 